\title{
POPULATION GENETIC STRUCTURE OF THE BAIRD'S POCKET GOPHER, GEOMYS BREVICEPS, IN EASTERN TEXAS
}

\author{
Sarah R. Welborn ${ }^{1}$ and Jessica E. Lightt,2
}

\begin{abstract}
AвSTRACT.-The Baird's pocket gopher (Geomys breviceps) is a solitary, fossorial rodent found throughout areas of Texas, Arkansas, Oklahoma, and Louisiana. These rodents are highly modified morphologically for an underground lifestyle, often resulting in limited vagility and isolated populations. Despite these unique characteristics, little is known about the population genetics of pocket gophers. We used mitochondrial and microsatellite data and performed a series of population genetic analyses to better understand the population structure and gene flow among a series of G. breviceps localities. Population genetic analyses supported high levels of gene flow among localities within $2 \mathrm{~km}$ of each other, with decreasing levels as distance between localities increased. Findings suggest that 2-3 localities function as one genetic cluster, resulting in a total of 3-4 total genetic clusters observed in this study. Results also suggest that the Baird's pocket gopher is capable of moving at least $2 \mathrm{~km}$, but further analyses should be completed to better understand dispersal distance in this fossorial species.
\end{abstract}

Resumen.-La tuza de Baird (Geomys breviceps) es un roedor fosorial, solitario, que se encuentra a través del territorio de Texas, Arkansas, Oklahoma, y Louisiana. Estos roedores están altamente modificados morfológicamente para la vida subterranea, resultando con frecuencia en vagilidad limitada y poblaciones aisladas. A pesar de estas características únicas, poco se sabe acerca de la genética de poblaciones de estas tuzas. Utilizamos datos mitocondriales y de microsatélites y realizamos una serie de análisis de genética de poblaciones para entender mejor la estructura poblacional y el flujo genético entre una serie de localidades de G. breviceps. Los análisis de genética de poblaciones apoyaron altos niveles de flujo genético entre localidades cercanas ( $2 \mathrm{~km}$ de distancia entre una y otra) con una disminución de éste conforme la distancia entre localidades se incremento. Los hallazgos sugieren que de 2-3 localidades funcionan como una agrupación genética, resultando en un total de 3-4 agrupaciones genéticas observadas en este estudio. Los resultados también sugieren que la tuza de Baird es capaz de moverse al menos $2 \mathrm{~km}$, pero análisis adicionales deben ser completados para entender mejor la distancia de dispersión en esta especie fosorial.

Pocket gophers are a group of solitary and fossorial rodents classified in the family Geomyidae. There are 6 genera and approximately 40 species of pocket gophers distributed throughout North and Central America (Merrit 2010). Pocket gophers belonging to the genus Geomys have been the subject of a variety of research studies focusing on phylogenetics, systematics, morphology, hybridization, cospeciation, site fidelity, and population structure (e.g., Dowler 1989, Demastes and Hafner 1993, Burt and Dowler 1999, Sudman et al. 2006, Chambers et al. 2009, King 2010). The Baird's pocket gopher (Rodentia: Geomyidae), Geomys breviceps, is common throughout the Brazos Valley region of Texas, and its larger distribution includes eastern Texas, Arkansas, Oklahoma, and western Louisiana (Sulentich et al. 1991, Schmidly 2004). Similar to other pocket gophers, G. breviceps is highly modified morphologically for a fossorial lifestyle
(Sulentich et al. 1991, Merrit 2010). Morphological specializations for digging include large ever-growing incisors and increased muscle mass and large, long claws at the anterior end of their bodies (Stein 2000). These anatomical modifications enable pocket gophers to dig elaborate and narrow burrow systems below the surface of the soil (Sulentich et al. 1991). Within these burrow systems, pocket gophers spend the majority of their lives building new tunnels and sealing tunnels that are no longer in use (Howard and Childs 1959, Sulentich et al. 1991).

Due to their level of specialization and overall morphology, G. breviceps and other pocket gopher species have relatively low vagility outside of their burrow systems (Patton et al. 1972, Nevo 1979, Patton and Feder 1981). Previous studies of pocket gophers have found that general activity is confined to the burrow system, with aboveground activity

\footnotetext{
${ }^{1}$ Department of Wildlife and Fisheries Sciences, Texas A\&M University, College Station, TX 77843.

${ }^{2}$ Corresponding author. Present address: Texas A\&M University, Department of Wildlife and Fisheries Sciences, 210 Nagle Hall, College Station, TX 77843. E-mail: jlight2@tamu.edu
} 
restricted to dispersal events and short foraging excursions (Howard and Childs 1959, Teipner et al. 1983, Connior and Risch 2010). The inability of pocket gophers to move well outside of the burrow system can translate to reduced dispersal capabilities, isolated populations, small effective population sizes, and limited gene flow among populations (Patton and Feder 1981, Hafner et al. 1983, Williams and Cameron 1984, Hafner et al. 1998, Burt and Dowler 1999, Connior and Risch 2010), and can result in the development and persistence of isolated populations (Burt and Dowler 1999), which can subsequently reduce heterozygosity (Williams and Baker 1976).

Despite the unique morphological adaptations and reduced genetic diversity of solitary species with isolated populations, little is known about pocket gopher population genetics. Herein, we use mitochondrial and microsatellite data to investigate population genetics among a series of localities of the Baird's pocket gopher found in and around the Brazos Valley, Texas. Determining the population genetic structure of $G$. breviceps populations may help to elucidate the role of morphological and behavioral modifications in structuring populations and gene flow within a solitary and territorial species.

\section{Methods}

Fifty specimens of $G$. breviceps were collected from 5 localities (10 specimens per locality) in Brazos and Grimes counties, Texas (Appendix 1). The 5 localities (Highway 47 North, Highway 47 South, Riverside Campus, Sheep Center, and Highway 6) were separated by distances ranging between $0.75 \mathrm{~km}$ and $58.68 \mathrm{~km}$ (Appendix 2). Notably, G. breviceps hybridizes with the distantly related Attwater's pocket gopher (Geomys attwateri) west of the Brazos River in Burleson and Milam counties, Texas (Honeycutt and Schmidly 1979, Tucker and Schmidly 1981, Dowler 1989, Burt and Dowler 1999). All specimens included in this study were located east of the Brazos River, ruling out the possibly of sampling $G$. attwateri or hybrids. Furthermore, all molecular data gathered as part of this study match unambiguously to G. breviceps (i.e., GenBank BLAST searches and unpublished data). All specimens were collected according to procedures approved by the Texas A\&M University
Animal Care and Use Committee and the American Society of Mammalogists (Sikes et al. 2011). All collected specimens were deposited in the Biodiversity Research and Teaching Collections at Texas A\&M University (Appendix 1).

Pocket gopher DNA was extracted from all tissues by using a DNeasy Tissue Kit (QIAGEN Inc., Valencia, CA) according to the manufacturer's instructions. Portions of 2 mitochondrial genes were amplified and sequenced: cytochrome oxidase $c$ subunit I (COI; 1469 base pairs [bp]) and NADH dehydrogenase 2 (ND2; $827 \mathrm{bp}$ ). COI and ND2 were amplified using the primers COI5285 and COI6929 (Spradling et al. 2004) and L5219ND2 and H6315ND2 (Sorenson et al. 1999), respectively. Polymerase chain reaction (PCR) amplifications were conducted in $25-\mu \mathrm{L}$ reactions containing $12 \mu \mathrm{L}$ of water, $10 \mu \mathrm{L}$ EmeraldAmp ${ }^{\circledR}$ MAX PCR Master Mix (Takara Bio Inc.), $1 \mu \mathrm{L}$ each of the forward and reverse primers, and $1 \mu \mathrm{L}$ of DNA. Double-stranded PCR amplifications for COI were performed with an initial denaturation of $95^{\circ} \mathrm{C}$ for 5 min followed by 30 cycles of $95{ }^{\circ} \mathrm{C}(1 \mathrm{~min}), 49^{\circ} \mathrm{C}$ (1 min), and $72{ }^{\circ} \mathrm{C}(2 \mathrm{~min})$, and a final extension of $72{ }^{\circ} \mathrm{C}$ for 5 min. Double-stranded PCR amplifications for ND2 were performed with an initial denaturation of $94{ }^{\circ} \mathrm{C}$ for $5 \mathrm{~min}$, followed by 30 cycles of $94{ }^{\circ} \mathrm{C}(30 \mathrm{~s}), 50{ }^{\circ} \mathrm{C}(30 \mathrm{~s})$, and $72{ }^{\circ} \mathrm{C}(90 \mathrm{~s})$, and a final extension of $72{ }^{\circ} \mathrm{C}$ (5 min). Amplified products were purified using EXOSap-IT (USB Corporation). All sequencing reactions were performed at the University of Florida DNA Sequencing Core Laboratory (following Light and Reed 2009) using the primers listed above and the following internal primers for COI: Mco-173f, Mco-1480r, and Mco-1345r (Hafner et al. 2007), and GcolF1, GcolR1, and CO1-570F (Spradling et al. 2004). Sequences were edited using Sequencher 4.9 (Gene Codes Corporation, Madison, WI) and aligned by eye. Se-AL v2.0a11 (Rambaut 1996) was used to remove primer sequences in reference to translated protein sequences. All sequences were submitted to GenBank (GenBank accession numbers KF542692-KF542741 for COI and KF5 42742-KF542791 for ND2).

All mitochondrial analyses were performed on each gene individually and the combined 2-gene data set (COI and ND2). Pairwise distances (uncorrected $p$ distances) of mitochondrial data were calculated in PAUP* version 
4.0b10 (Swofford 2002). Number of haplotypes and haplotype diversity was determined using DNAsp, v. 5.10.01 (Rozas et al. 2003). Haplotype networks were constructed using the program TCS version 1.21 to visualize relationships among the localities (Clement et al. 2000). In TCS, haplotype connectivity was set to a $95 \%$ parsimony criterion (with the assumption of equal weighting among mutations), and all gaps were treated as missing data. Population structure was assessed using an analysis of molecular variance (AMOVA) in Arlequin v. 3.5 (Excoffier et al. 2005). $\Phi$ statistics ( $F$-statistic analogs) were used to account for varying levels of genetic distance among haplotypes, and pairwise estimation of $\Phi_{\mathrm{CT}}$ (degree of differentiation among all populations) and $\Phi_{\mathrm{ST}}$ (degree of differentiation within populations) were determined using 10,000 randomization replicates to assess significance, with each population predefined by locality (Appendix 1). Isolation by distance (IBD) was determined using the program IBDWS v 3.23 (Jensen et al. 2005) to test for a correlation between genetic and geographic distances. In all IBD analyses, genetic distance $\left(\Phi_{\mathrm{ST}}\right)$ was used along with distances obtained from ArcMap10 (ESRI 2011). Analyses were run for 10,000 randomizations, and significance was determined statistically through use of a Mantel test.

Ten polymorphic microsatellite loci (Gbr06, Gbr09, Gbr10, Gbr14, Gbr15, Gbr25, Gbr26, Gbr27, Gbr33, Gbr36), previously identified in Welborn et al. (2012), and 4 polymorphic microsatellite loci ( $\mathrm{Tm} 1, \mathrm{Tm} 2, \mathrm{Tm} 6, \mathrm{Tm} 7)$, previously identified in Steinberg (1999), were genotyped for all pocket gophers at each locality. PCR amplifications for each locus were performed following Karlsson et al. (2008). PCR products were loaded onto a polyacrylamide gel and run using an ABI Prism 377 DNA Sequencer (Biosystematics Center, College Station, TX) to separate and visualize amplification products. Genescan 3.1.2 (Applied Biosystems) was utilized to visualize the gel for analysis, and data were imported into GenoTyper 2.5 (Applied Biosystems) for allelecalling. Microsatellite allele scores also were confirmed by eye.

Microsatellite data were organized per locality, and locus and input files were formatted using the program Convert v. 1.31 (Glaubitz 2004). Observed heterozygosity, expected heterozygosity, and Hardy-Weinberg equilibrium were determined with Genepop v. 4.1 (Rousset 2008) and Arlequin v. 3.5 (Excoffier et al. 2005). Number of alleles and allelic richness were calculated for each locality in Fstat v. 2.9.3.2 (Goudet 1995). $F_{\mathrm{ST}}$ statistics were calculated for each locality using Arlequin v. 3.5 (Excoffier et al. 2005). Population structure also was assessed using AMOVA (Excoffier et al. 2005), in which each population was predefined by locality and significance was determined using 10,000 randomization replicates.

Spatial genetic analyses, using pairwise geographic and genetic distances, were performed using the genetic spatial autocorrelation option (Peakall et al. 2003, Banks and Peakall 2012) in GenAlEx 6.4 (Peakall and Smouse 2006, 2012). The genetic spatial autocorrelation option uses pairwise comparisons to estimate $r$, an autocorrelation coefficient, for specified distance classes. Given the distances among the 5 collection localities (Appendix 2), distance classes were estimated at $2-\mathrm{km}$ intervals up to 60 $\mathrm{km}$ to determine the geographic distances for which spatial autocorrelation is significant (Cullingham et al. 2008). Permutation and bootstrapping (999 iterations) were used to test the hypothesis of no spatial structure. Analyses were conducted for males and females $(n=$ $50)$, females only $(n=33)$, and males only $(n$ $=17$ ) to test for sex-biased philopatry.

The Bayesian-based program Structure 2.2.1 (Pritchard et al. 2000) was used to determine the most likely clusters of genetic variation from a predefined $K$ (number of clusters as defined by the user). The data were input with an admixture model, and 5 runs were performed for clusters $K=1-5$. Each run was completed with Markov chain-Monte Carlo repetitions with a burn-in of 10,000 followed by 100,000 repetition steps (Evanno et al. 2005). Structure Harvester v 0.6 (Earl and vonHoldt 2012) was used to determine the $\Delta K$, mean ln Prob(Data) (Evanno et al. 2005), and the most likely number of clusters $(K)$. Isolation by distance (IBD) was also determined for microsatellite data using the program IBDWS v 3.23 (Jensen et al. 2005) as described above, except genetic distances $\left(F_{\mathrm{ST}}\right)$ were used to test for a correlation between genetic and geographic distances. Migrate- $\mathrm{N}$ v 3.0.3 (Beerli and Felsenstein 1999) was used to estimate levels of gene flow among localities. Initial runs were completed to estimate 
priors for $M$ (mutation-scaled migration rate) and $\theta$ (theta). The final run was performed twice at different starting points with one long chain to better verify convergence. Burn-in was set to 10,000 and was then followed by 500,000 repetitions. A heated-chain scheme was used to thoroughly search through parameter space.

\section{Results}

Results for the individual mitochondrial gene (COI and ND2) and the combined 2-gene data set were similar. Only the results for the combined 2-gene data set are presented here; individual gene results are available upon request. Pairwise distances of the combined 2gene data set showed high levels of similarity among localities, ranging from 0.007 to 0.012 . Uncorrected $p$ distances within localities were small, ranging from 0.007 to 0.001 . Number of haplotypes (and haplotype diversity) for the combined 2-gene data set was $20(0.9257)$ and the haplotype network showed extensive haplotype sharing among the Highway 47 North, Highway 47 South, and Riverside localities. The Sheep Center and Highway 6 localities were represented by 2 and 4 haplotypes, respectively (haplotype network available on Figshare: http://dx.doi.org/10.6084/m9.figshare .769352). Initial AMOVA analyses were run to examine variation among localities that were $<2 \mathrm{~km}$ apart (Appendix 2): Highway 47 North and Highway 47 South, as well as Highway 47 North, Highway 47 South, and the Riverside Campus localities. For the Highway 47 North and South comparisons, there were high levels of variation within populations $(100 \%)$ and low and nonsignificant levels of variation among populations, suggesting that these 2 localities can be grouped together. For the Highway 47 North, Highway 47 South, and Riverside comparison, although there were high levels of variation within populations $(86 \%)$, variation between Riverside Campus and both Highway 47 populations was significant, indicating population structure. To be conservative in the assessment of population structure, AMOVA analyses were run with all 5 localities, 4 localities (grouping Highway 47 North and Highway 47 South together), and 3 localities (grouping Highway 47 North, Highway 47 South, and Riverside Campus together). Results from AMOVA analyses of the combined 2-gene data set showed significant signs of population structure among the $5 \mathrm{G}$. breviceps localities (Table 1). For all comparisons, pairwise estimations of $\Phi_{\mathrm{CT}}$ were significant, with more variation apparent among the populations (variation among populations increased when populations $<2 \mathrm{~km}$ apart were grouped together; Table 1). IBD analyses showed a significant relationship between genetic and geographic distances (correlation coefficient $r=$ $0.5713, P=0.008)$.

General summary data from the microsatellite data show that all 14 loci were polymorphic except locus Tm6 at Riverside Campus and loci Tm2 and Tm6 at Sheep Center (summary statistics available on Figshare: http://dx.doi.org/10.6084/m9.figshare.769352). The most polymorphic loci were Gbr26 and $\operatorname{Tm} 7$, with 17 alleles, and the least polymorphic locus was Gbr36, with 2 alleles. The number of alleles per locus and allelic richness ranged from 2 to 10 . Observed heterozygosity was lowest for Highway 47 North $\left(\mathrm{H}_{\mathrm{O}}\right.$ $=0.100$ at Gbr36 and Tm2), Highway 47 South $\left(\mathrm{H}_{O}=0.100\right.$ at $\left.T m 2\right)$, and Highway 6 $\left(\mathrm{H}_{\mathrm{O}}=0.100\right.$ at $\left.T m 6\right)$, and expected heterozygosity was lowest for Highway 47 North $\left(\mathrm{H}_{\mathrm{E}}\right.$ $=0.100$ at Gbr36 and Tm2). Individuals from Highway 47 North, Highway 47 South, and Sheep Center showed signs of significant deviation from Hardy-Weinberg equilibrium at locus Gbr26. Individuals from Highway 6 also showed signs of significant deviation from Hardy-Weinberg equilibrium at loci $T m 1$ and Tm6. Results from preliminary Structure and AMOVA analyses did not differ when run with or without the loci deviating from HardyWeinberg equilibrium (results available upon request); therefore, all loci were included in all subsequent analyses. Similar analyses were run with and without loci that showed signs of null alleles and linkage disequilibrium in Welborn et al. (2012). Results did not differ, and thus these loci were included in the subsequent analyses.

Results from AMOVA analyses of the microsatellite data showed significant variation among populations and individuals of the $5 \mathrm{G}$. breviceps localities (Table 1). Similar to the mitochondrial analyses, initial AMOVA analyses were run to examine variation among localities that were $<2 \mathrm{~km}$ apart: Highway 47 North and Highway 47 South, as well as Highway 47 North, Highway 47 South, and the Riverside 
TABLE 1. AMOVA among 5, 4, and 3 Geomys breviceps localities using the 2-gene mitochondrial and microsatellite data sets (see text for explanation of population assignment). Significance of variance component $(P)$ was tested by permutation according to Excoffier et al. (2005).

\begin{tabular}{|c|c|c|c|c|}
\hline Source of variation & Variance components & $\%$ of variation & Fixation index & $P$ \\
\hline \multicolumn{5}{|l|}{ MITOCHONDRIAL DNA } \\
\hline \multicolumn{5}{|l|}{ All 5 localities } \\
\hline Among populations & 5.224 & 53.74 & & \\
\hline Within populations & 4.498 & 46.26 & $\Phi_{\mathrm{ST}}=0.537$ & $<0.0001$ \\
\hline \multicolumn{5}{|c|}{4 Localities (Highway 47 North and Highway 47 South grouped) } \\
\hline Among populations & 5.143 & 50.25 & $\Phi_{\mathrm{CT}}=0.502$ & $<0.0001$ \\
\hline Within populations & 4.498 & 43.94 & $\Phi_{\mathrm{ST}}=0.561$ & 0.089 \\
\hline \multicolumn{5}{|c|}{3 Localities (Highway 47 North, Highway 47 South, and Riverside Campus grouped) } \\
\hline Among populations & 5.015 & 44.67 & $\Phi_{\mathrm{CT}}=0.447$ & $<0.0001$ \\
\hline Within populations & 4.498 & 40.06 & $\Phi_{\mathrm{ST}}=0.599$ & 0.105 \\
\hline \multicolumn{5}{|l|}{ Microsatellite DNA } \\
\hline \multicolumn{5}{|l|}{ All 5 localities } \\
\hline Within populations & 0.732 & 14.612 & $F_{\mathrm{IS}}=0.000$ & $<0.5578$ \\
\hline Among populations & 0.001 & 0.001 & $F_{\mathrm{ST}}=0.146$ & $<0.0001$ \\
\hline Among individuals & 4.280 & 85.388 & $F_{\mathrm{IT}}=0.144$ & $<0.0001$ \\
\hline \multicolumn{5}{|c|}{4 Localities (Highway 47 North and Highway 47 South grouped) } \\
\hline Within populations & 0.782 & 15.407 & $F_{\mathrm{IS}}=0.003$ & $<0.4821$ \\
\hline Among populations & 0.013 & 0.251 & $F_{\mathrm{ST}}=0.154$ & $<0.0001$ \\
\hline Among individuals & 4.280 & 84.342 & $F_{\mathrm{IT}}=0.157$ & $<0.0001$ \\
\hline \multicolumn{5}{|c|}{3 Localities (Highway 47 North, Highway 47 South, and Riverside Campus grouped) } \\
\hline Within populations & 0.794 & 15.254 & $F_{\mathrm{IS}}=0.030$ & $<0.1000$ \\
\hline Among populations & 0.133 & 2.558 & $F_{\mathrm{ST}}=0.153$ & $<0.0001$ \\
\hline Among individuals & 4.280 & 82.188 & $F_{\mathrm{IT}}=0.178$ & $<0.0001$ \\
\hline
\end{tabular}

Campus localities. These initial runs showed high levels of variation within populations (93\% for both comparisons). As in the mitochondrial analyses, variation among the Highway 47 North and Highway 47 South localities was not significant, suggesting that these localities can be grouped together. In contrast, variation among the Highway 47 North, Highway 47 South, and Riverside localities was significant, indicating population structure. However, to be conservative in the assessment of population structure, AMOVA analyses were run using all 5 localities, 4 localities, and 3 localities (see mitochondrial genetic variation in Table 1). Regardless of how the localities were grouped, there was significant variation among populations $\left(F_{\mathrm{ST}}\right)$ and among individuals $\left(F_{\text {IT }}\right)$, whereas variation within populations $\left(F_{\text {IS }}\right)$ was not significant (Table 1).

A significant positive spatial autocorrelation was found for all samples and all data sets (females plus males, females only, and males only) collected at distances of $2 \mathrm{~km}$. For distances $>10 \mathrm{~km}$, significant negative spatial autocorrelations were found for most data sets. The only exceptions were nonsignificant and positive (but close to zero at 0.002 ) autocorrelations for males at $10 \mathrm{~km}$, nonsignificant and positive (but close to zero at 0.018 ) autocorrelations for females at $42 \mathrm{~km}$, and nonsignificant yet negative autocorrelations for females plus males at $42 \mathrm{~km}$.

A $K$ of 3 was the most likely set of microsatellite genetic clusters in Structure and Structure Harvester, with a $\Delta \ln \operatorname{Prob}($ Data) of 192.86. In this analysis, Highway 47 North, Highway 47 South, and Riverside Campus were clustered together to form one defined group (Fig. 1A). A $K$ of 4 also was likely (Fig. 1B) but did not score as well as 3 clusters, with a $\Delta \ln \operatorname{Prob}($ Data) of 60.19. A $K$ of 1 and a $K$ of 5 were the least likely. IBD analyses showed a significant relationship between genetic and geographic distances (correlation coefficient $r=0.7655, P=0.008)$. Migrate-N estimations of levels of gene flow were performed for groupings as presented in AMOVA analyses above: all 5 localities, 4 localities, and 3 localities; all analyses produced similar results (Table 2). Estimates of $M$ (mutationscaled migration rate) ranged from 0.241 to 0.317 , and estimates of $\theta$ (theta) ranged from 2.201 to 3.925 (Table 2). Estimates of $M$ were moderate when examined among localities $<2$ $\mathrm{km}$ apart (range 0.398-0.464). These estimates increased to $0.520-0.701$ when comparing 

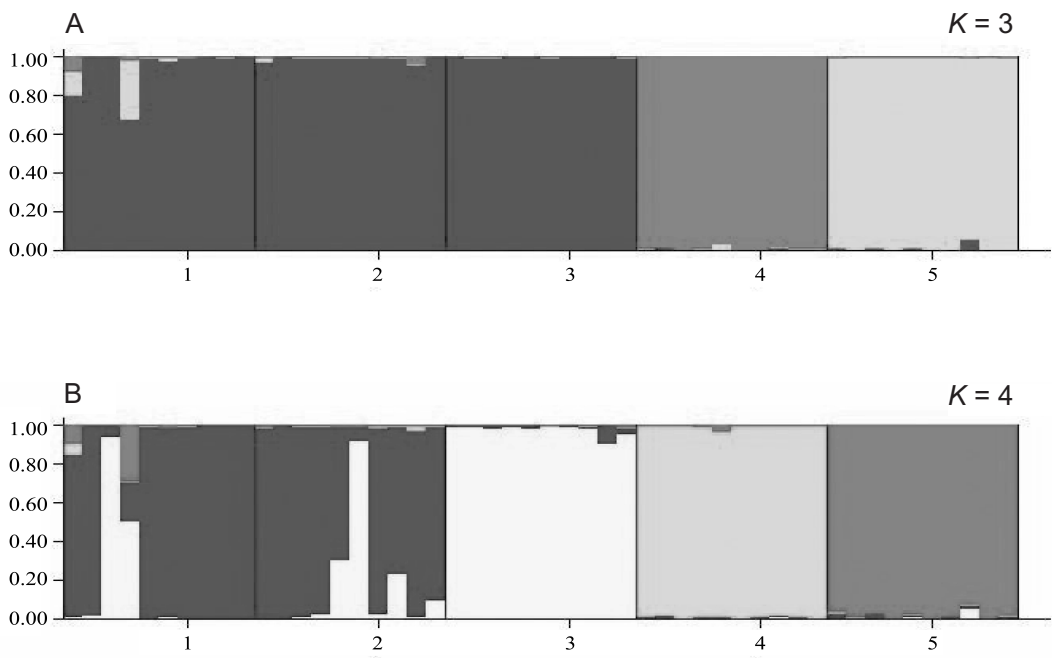

Fig. 1. Bar plot produced by Structure utilizing microsatellite data from all 5 Geomys breviceps localities. The Highway 47 North, Highway 47 South, and Riverside Campus localities are grouped together, suggesting 3 genetic population clusters: (A) $K=3$; (B) $K=4$.

TABLE 2. Estimated $M$ (mutation-scaled migration rate) and $\theta$ (theta) results from Migrate-N comparing 3 localities of Geomys breviceps (grouping Highway 47 North, Highway 47 South, and Riverside Campus together, as represented by the abbreviation NSR). a $95 \%$ confidence intervals (95\% CI) are also shown.

\begin{tabular}{lcc}
\hline Population comparison & $M$ & $95 \%$ CI \\
\hline NSR to Sheep Center & 0.289 & $0.104-0.490$ \\
NSR to Highway 6 & 0.317 & $0.111-0.553$ \\
Sheep Center to NSR & 0.299 & $0.129-0.483$ \\
Sheep Center to Highway 6 & 0.282 & $0.098-0.486$ \\
Highway 6 to NSR & 0.276 & $0.111-0.456$ \\
Highway 6 to Sheep Center & 0.241 & $0.071-0.426$ \\
\hline Population & $\theta$ & $95 \%$ CI \\
\hline NSR & 3.925 & $3.012-4.872$ \\
Sheep Center & 3.147 & $2.028-4.380$ \\
Highway 6 & 2.201 & $1.440-3.012$ \\
\hline
\end{tabular}

aResults from comparisons among 4 and 5 localities are available upon request.

only Highway 47 North, Highway 47 South, and Riverside Campus, and to 0.693-0.732 when comparing only Highway 47 North to Highway 47 South. These high $M$ estimates indicate that some or all of these localities may be functioning as one population. However, it is important to note that the confidence intervals were extremely large and overlapping in the comparison of localities that were $<2 \mathrm{~km}$ apart, making interpretation of $M$ difficult.

\section{Discussion}

In general, population genetic studies focusing on a solitary species with low vagility, such as the Baird's pocket gopher, are rare (e.g., Hambuch and Lacey 2000, Connior and Risch 2010, Lopes and De Freitas 2012, Mapelli et al. 2012). This study found that both mitochondrial and microsatellite data were informative in understanding population processes across a series of localities of $G$. breviceps in the Brazos Valley of eastern Texas. Our findings support high levels of gene flow among nearby populations $(<2 \mathrm{~km}$ apart), with decreasing gene flow as distance increases (after approximately $9 \mathrm{~km}$; Tables 1 and 2). These results indicate that Highway 47 North, Highway 47 South, and Riverside Campus are functioning as 1-2 populations or genetic clusters, and 
Sheep Center and Highway 6 are each functioning as separate clusters (Tables 1, 2; Fig. 1).

The results of this study provide insight regarding movement and dispersal of the Baird's pocket gopher. The high levels of gene flow and significantly positive spatial autocorrelations among the Highway 47 localities and Riverside Campus (distances of $\sim 2 \mathrm{~km}$ ) suggest that the highway that separates these localities does not hinder movement of pocket gophers. The soils under highways are often extremely compacted and rocky, and could possibly hinder burrowing (Griscom et al. 2010), suggesting that aboveground movement would be necessary. Highway 47 (which separates the Highway 47 localities) was constructed in 1987 and has driven aboveground movement among these localities for at least 20 years (Estridge 2008). Even with limited mobility above the soil due to its morphological adaptations for a fossorial lifestyle (Sulentich et al. 1991, Stein 2000, Merrit 2010), G. breviceps is able to move distances of at least $2 \mathrm{~km}$ above ground. Genetic spatial autocorrelation analyses, however, indicate that dispersal distances $>10 \mathrm{~km}$ are unlikely. In contrast, population genetic analyses support the conclusion that there is some gene flow occurring among all 5 localities (although levels of gene flow are reduced when comparing the Highway 6 population to the other 4 populations, which are separated by over $48 \mathrm{~km}$ ). The evidence for gene flow suggests that that G. breviceps may be capable of moving large distances (albeit rarely) or that there was once a much larger, continuous population throughout the Brazos Valley. Further studies examining additional localities will be necessary to determine the largest possible distance G. breviceps can move above ground.

IBD analyses can be used to investigate evidence of sex-biased dispersal when comparing mitochondrial and nuclear DNA. High levels of isolation by distance would suggest that dispersal is infrequent; whereas low levels of isolation by distance would suggest the opposite for either females or males depending on the genetic marker examined. Significant levels of IBD are seen here in both mitochondrial and microsatellite data sets, with high correlations between geographic and genetic distances. This suggests that as geographic distance increases, genetic differentiation among populations also increases, supporting decreasing levels of dispersal at farther distances.
Unfortunately, with significant results for both mitochondrial and microsatellite analyses, these data cannot be used to determine if $G$. breviceps undergoes male- or female-biased dispersal. Genetic spatial autocorrelation analyses can also be used to assess sex-biased dispersal. However, results reported herein were similar regardless of the gender analyzed, supporting a lack of sex-biased dispersal in G. breviceps.

In their examination of G. attwateri (a pocket gopher species located near and often hybridizing with G. breviceps), Williams and Cameron (1984) found that the majority of dispersing individuals were juveniles caught in aboveground traps. Aboveground dispersal by juveniles also has been observed in the pocket gopher genus Thomomys (Howard and Childs 1959), with dispersal distances up to $500 \mathrm{~m}$, depending upon surrounding environment (Vaughan 1963, Hafner et al. 1983, Smith et al. 1983, Daly and Patton 1990, Hafner et al. 1998). In a recent study focusing on G. breviceps site fidelity and population structure, King (2010) found high site fidelity and that juveniles moved the largest distances (up to $46 \mathrm{~m}$; maximum dispersal distance is unknown due to the limited geographic scale of the study). Based on these previous findings, future studies using juveniles (as well as adult males and females) from a variety of distance classes will be necessary to better understand dispersal distances in the Baird's pocket gopher.

\section{Conclusion}

Overall, a general relationship between distance and level of gene flow is seen in this study of the Baird's pocket gopher in eastern Texas: as the distance among localities increases, levels of gene flow decrease. Results from this research can aid in better understanding levels of gene flow within G. breviceps and can possibly be useful in understanding population processes in other fossorial species. Additional research including more localities, samples per locality, and other species can facilitate a better understanding of population structure and the processes of speciation, gene flow, and dispersal in both solitary and social fossorial species.

\section{ACKNOWLEDGMENTS}

We thank G. Voelker, B. Murphy, and the Light, Conway, and Voelker labs for helpful 
comments on earlier drafts of this manuscript. "Spatial" thanks to W. Brashear for help with the spatial autocorrelation analyses, J. Garner for providing field assistance, and J. Fernández for providing the Spanish translation of the abstract. The authors acknowledge the Texas A\&M University Brazos HPC Cluster that contributed to the research reported here (http://brazos.tamu.edu). This is publication number 242 of the Center for Biosystematics and Biodiversity and publication number 1471 of the Biodiversity Research and Teaching Collections at Texas A\&M University.

\section{Literature Cited}

Banks, S.C., AND R. Peakall. 2012. Genetic spatial autocorrelation can readily detect sex-biased dispersal. Molecular Ecology 21:2092-2105.

Beerli, P., And J. Felsenstein. 1999. Maximum-likelihood estimation of migration rates and effective population numbers in two populations using a coalescent approach. Genetics 152:763-773.

Burt, M.S., AND R.C. Dowler. 1999. Biochemical systematics of Geomys breviceps and two chromosomal races of Geomys attwateri in Eastern Texas. Journal of Mammalogy 80:779-809.

Chambers, R.R., P.D. Sudman, and R.D. Bradley. 2009. A phylogenetic assessment of pocket gophers (Geomys): evidence from nuclear and mitochondrial genes. Journal of Mammalogy 90:537-547.

Clement, M., D. Posada, and K.A. Crandall. 2000. TCS: a computer program to estimate gene genealogies. Molecular Ecology 9:1657-1659.

Connior, M.B., AND T.S. Risch. 2010. Home range and survival of the Ozark Pocket Gopher (Geomys bursarius ozarkensis) in Arkansas. American Midland Naturalist 164:80-90.

Cullingham, C.I., B.A. Pond, C.J. Kyle, E.E. Rees, R.C. RosatTe, AND B.N. White. 2008. Combining direct and indirect genetic methods to estimate dispersal for informing wildlife disease management decisions. Molecular Ecology 17:4874-4886.

Daly, J.C., And J.L. Patton. 1990. Dispersal, gene flow, and allelic diversity between local populations of Thomomys bottae pocket gophers in the coastal ranges of California. Evolution 44:1283-1294.

Demastes, J.W., and M.S. Hafner. 1993. Cospeciation of pocket gophers (Geomys) and their chewing lice (Geomydoecus). Journal of Mammalogy 74:521-530.

Dowler, R.C. 1989. Cytogenetic studies of three chromosomal races of pocket gophers (Geomys bursarius) at hybrid zones. Journal of Mammalogy 70:253-266.

EARL, D.A., AND B.M. vONHOLDT. 2012. STRUCTURE HARVESTER: a website and program for visualizing STRUCTURE output and implementing the Evanno method. Conservation Genetics Resources 4:359-361

[ESRI] Environmental Systems Research Institute. 2011. ArcGIS Desktop: Release 10. ESRI, Redlands, CA.

Estridge, H.L. 2008. Growth opportunities. The Bryan College Station Eagle [3 April 2008]. Available from: http://www.theeagle.com/business/growthoppor tunities

Evanno, G., S. Regnaut, and J. Goudet. 2005. Detecting the number of clusters of individuals using the software STRUCTURE: a simulation study. Molecular Ecology 14:2611-2620.

Excoffier, L., G. Laval, and S. Schneider. 2005. Arlequin (version 3.0): an integrated software package for population genetics data analysis. Evolutionary Bioinformatics 1:47-50.

GLAUBITZ, J.C. 2004. CONVERT: a user-friendly program to reformat diploid genotypic data for commonly used population genetic software packages. Molecular Ecology Notes 4:309-310.

GoudET, J. 1995. FSTAT (Version 1.2): a computer program to calculate $F$-statistics. Journal of Heredity $86: 485-486$.

Griscom, H.R., D.A. Keinath, and M. Andersen. 2010. Pocket gopher surveys in southwestern Wyoming; final project report. Pages 1-39 in Report prepared for the Wyoming Game and Fish Department. Wyoming Natural Diversity Database, University of Wyoming, Laramie, WY.

Hafner, J.C., D.J. Hafner, J.L. Patton, and M.F. Smith. 1983. Contact zones and the genetics of differentiation in the pocket gopher Thomomys bottae (Rodentia: Geomyidae). Systematic Zoology 32:1-20.

Hafner, J.C., J.E. Light, D.J. Hafner, M.S. Hafner, E. RedDington, D.S. Rogers, and B.R. RiddLe. 2007. Basal clades and molecular systematics of heteromyid rodents. Journal of Mammalogy 88:1129-1145.

Hafner, M.S., J.W. Demastes, D.J. Hafner, T.A. Spradling, P.D. Sudian, and S.A. Nadler. 1998. Age and movement of a hybrid zone: implications for dispersal distance in pocket gophers and their chewing lice. Evolution 52:278-282.

Hambuch, T.M., and E.A. Lacey. 2000. Contrasting patterns of MHC and microsatellite diversity in social and solitary tuco-tucos (Rodentia: Ctenomyidae). Pages 542-554 in M. Kasahara, editor, Major histocompatibility complex: evolution, structure and function. 6th International Workshop on Major Histocompatibility Complex Evolution, Hayama, Japan.

Honeycutt, R.L., And D.J. Schmidly. 1979. Chromosomal and morphological variation in the plains pocket gopher, Geomys bursarius, in Texas and adjacent states. Occasional Papers of the Museum of Texas Tech University 58:1-54.

Howard, W.E., AND H.E. ChILDS. 1959. Ecology of pocket gophers with emphasis on Thomomys bottae mewa. Hilgardia 29:277-358.

Jensen, J.L., A.J. BOHONAK, AND S.T. KeLLey. 2005. Isolation by distance, web service. BMC Genetics 6 .

Karlsson, S., M.A. Renshaw, C.E. Rexroad, and J.R. GOLD. 2008. PCR primers for 100 microsatellites in red drum (Sciaenopsocellatus). Molecular Ecology Resources 8:393-398.

KING, K.N. 2010. Site fidelity and population structure of a solitary subterranean rodent, Geomys breviceps, in southwestern Arkansas. Masters thesis, University of Arkansas at Little Rock, AR.

Light, J.E., AND D.L. REED. 2009. Multigene analysis of phylogenetic relationships and divergence times in primate sucking lice (Phthiraptera: Anoplura). Molecular Phylogenetics and Evolution 50:376-390.

Lopes, C.M., AND T.R.O. De Freitas. 2012. Human impact in naturally patched small populations: genetic 
structure and conservation of the burrowing rodent, tuco-tuco (Ctenomys lami). Journal of Heredity 103:672-681.

Mapelli, F.J., M.S. Mora, P.M. Mirol, and M.J. Kittlein. 2012. Population structure and landscape genetics in the endangered subterranean rodent Ctenomys porteousi. Conservation Genetics 13:165-181.

Merrit, J.F. 2010. The biology of small mammals. Johns Hopkins University Press, Baltimore, MD.

Nevo, E. 1979. Adaptive convergence and divergence of subterranean mammals. Annual Review of Ecology and Systematics 10:269-308

Patton, J.L., And J.H. Feder. 1981. Microspatial genetic heterogeneity in pocket gophers: non-random breeding and drift. Evolution 35:912-920.

Patton, J.L., R.K. Selander, and M.H. Smith. 1972. Genetic variation in hybridizing populations of gophers (genus: Thomomys). Systematic Zoology 21:263-270.

Peakall, R., M. Ruibal, and D.B. Lindenmayer. 2003. Spatial autocorrelation analysis offers new insights into gene flow in the Australian bush rat, Rattus fuscipes. Evolution 57:1182-1195.

Peakall, R., and P.E. Smouse. 2006. GenAlEx 6: genetic analysis in Excel. Population genetics software for teaching and research. Molecular Ecology Notes 6:288-295.

2012. GenAlEx 6.5: genetic analysis in Excel. Population genetic software for teaching and research—an update. Bioinformatics 28:2537-2539.

Pritchard, J.K., M. Stephens, and P. Donnelly. 2000. Inference of population structure using multilocus genotype data. Genetics 155:945-959.

Rambaut, A. 1996. Se-AL: sequence alignment editor. University of Oxford. Available from: http://tree.bio .ed.ac.uk/software/seal/

Rousset, F. 2008. GENEPOP '007: a complete reimplementation of the GENEPOP software for Windows and Linux. Molecular Ecology Resources 8:103-106.

Rozas, J., J.C. Sanchez-DelBarrio, X. Messeguer, and R. ROZAS. 2003. DNASP, DNA polymorphism ana lyses by the coalescent and other methods. Bioinformatics 19:2496-2497.

Schmidly, D.J. 2004. The mammals of Texas. University of Texas Press, Austin, TX.

Sikes, R.S., W.L. Gannon, and the Animal Care and Use Committee of the American Society of MamMALOGISTS. 2011. Guidelines of the American Society of Mammalogists for the use of wild mammals in research. Journal of Mammalogy 92:235-253.

Smith, M.F., J.L. Patton, J.C. Hafner, and D.J. Hafner. 1983. Thomomys bottae pocket gophers of the Central Rio Grande Valley, New Mexico: local differentiation, gene flow and historical biogeography.
Occasional Papers. The Museum of Southwestern Biology 2:1-16.

Sorenson, M.D., J.C. Ast, D.E. Dimcheff, T. Yuri, And D.P. MindeLL. 1999. Primers for a PCR-based approach to mitochondrial genome sequencing in birds and other vertebrates. Molecular Phylogenetics and Evolution 12:105-114.

Spradling, T.A., S.V. Brant, M.S. Hafner, and C.J. DiCKERSON. 2004. DNA data support rapid radiaton of pocket gopher genera (Rodentia: Geomyidae). Journal of Mammalian Evolution 11:105-125.

StEIn, B.R. 2000. Morphology of subterranean rodents. Pages 19-61 in E.A. Lacey, J.L. Patton, and G.N. Cameron, editors, Life underground: the biology of subterranean rodents. University of Chicago Press, Chicago, IL.

SteinberG, E.K. 1999. Characterization of polymorphic microsatellites from current and historic populations of North American pocket gophers (Geomyidae: Thomomys). Molecular Ecology 8:1075-1092.

Sudman, P.D., J.K. Wickliffe, P. Horner, M.J. Smolen, J.W. BICKHAM, AND R.D. BRADLEy. 2006. Molecular systematics of pocket gophers of the genus Geomys. Journal of Mammalogy 87:668-676.

Sulentich, J.M., L.R. Williams, and G.N. Cameron. 1991. Geomys breviceps. Mammalian Species 338.

SWOFFORD, D.L. 2002. PAUP*: phylogenetic analysis using parsimony (*and other methods) version $4.0 \mathrm{~b} 10$. Sinauer Associates, Inc., Sunderland, MA.

Teipner, C.L., E.O. Garton, And L. Nelson. 1983. Pocket gophers of forest ecosystems. USDA General Technical Report INT-154, Intermountain, Forest and Range Experimental Station, Ogden, UT.

Tucker, P.K., AND D.J. SchmidLy. 1981. Studies of a contact zone among three chromosomal races of Geomys bursarius in east Texas. Journal of Mammalogy 62: 258-272.

Vaughan, T.A. 1963. Movements made by two species of pocket gophers. American Midland Naturalist 69: 367-372.

Welborn, S.R., M.A. Renshaw, and J.E. Light. 2012. Characterization of 10 polymorphic loci in the Baird's pocket gopher (Geomys breviceps) and cross amplification in other gopher species. Conservation Genetics Resources 4:467-469.

Williams, L.R., and G.N. Cameron. 1984. Demography of dispersal in Attwater's pocket gopher (Geomys attwateri). Journal of Mammalogy 65:67-75.

Williams, S.L., AND R.J. BaKer. 1976. Vagility and local movements of pocket gophers (Geomyidea: Rodentia). American Midland Naturalist 96:303-316.

Received 13 September 2013 Accepted 30 May 2014 
Appendix 1. Geomys breviceps specimens examined in this study listed by locality and museum acronym. All specimens are deposited in the Biodiversity Research and Teaching Collections (TCWC) at Texas A\&M University.

Highway 47 North - Texas: Brazos Co., Bryan, Highway 47N 0.7 mi S of Texas Highway 21 exit, $30^{\circ} 38.132^{\prime} \mathrm{N}, 96^{\circ}$ 26.859' W (TCWC 60719-60723, 61029, 61030, 61926-61928).

Highway 47 South - Texas: Brazos Co., Bryan, Highway 47S $0.7 \mathrm{mi} \mathrm{S}$ of Texas Highway 21 exit, $30^{\circ} 38.092^{\prime}$ N, $96^{\circ} 26.885^{\prime}$ W (TCWC 60718, 60756, 60757, 61026-61028, 61191, 62454-62456).

Riverside Campus - Texas: Brazos Co., Bryan, Texas A\&M University Riverside Campus front pasture, $30^{\circ} 38.453^{\prime} \mathrm{N}, 96^{\circ}$ 27.722' W (TCWC 61189, 61190, 61192, 61193, 61913, 61924, 61925, 62451-62453).

Sheep Center - Texas: Brazos Co., College Station, Texas A\&M University Sheep Center pastures, $30^{\circ} 33.760^{\prime} \mathrm{N}, 96^{\circ}$ 24.548' W (TCWC 60859-60862, 60884-60887, 61194, 61195).

Highway 6 - Texas: Grimes Co., Navasota, Roadside next to Faith Outreach Center, $30^{\circ} 21.485^{\prime}$ N, $96^{\circ} 03.716^{\prime} \mathrm{W}$ (TCWC 60889-60893, 61266-61270).

APPENDIX 2. Rounded distances $(\mathrm{km})$ between the 5 localities of Geomys breviceps used in this study. The Highway 47 localities are separated by a small stretch of highway. Distances were obtained using ArcMap10 (ESRI 2011).

\begin{tabular}{lccccc}
\hline & $\begin{array}{c}\text { Highway } 47 \\
\text { North }\end{array}$ & $\begin{array}{c}\text { Highway } 47 \\
\text { South }\end{array}$ & $\begin{array}{c}\text { Riverside } \\
\text { Campus }\end{array}$ & $\begin{array}{c}\text { Sheep } \\
\text { Center }\end{array}$ & Highway 6 \\
\hline Highway 47 North & - & - & & \\
Highway 47 South & 0.750 & 1.600 & - & - & - \\
Riverside Campus & 1.850 & 9.790 & 11.300 & 48.102 & - \\
Sheep Center & 9.975 & 56.730 & 58.680 & \\
Highway 6 & 56.550 & &
\end{tabular}

